\title{
Economic Exploitation of the Saudi Working Woman: Types and Reasons: Towards Indicators of Precautionary Measures
}

\author{
Maisoun Ali N Alfayiz \\ Social Work College, Princess Nora bint Abdulrahman, University, Kingdom of Saudi Arabia
}

Copyright (C) 2015 Horizon Research Publishing All rights reserved.

\begin{abstract}
This study aimed at identifying the extent of the prevalence of Economic exploitation of the Saudi woman and revealing the level of the financial exploitation which the working women face. The study also aimed at identifying types of the Saudi woman's economic exploitation and the reasons that lead for the economic exploitation. To achieve the objectives of the study, the researcher applied the social survey approach. The population of the study which consisted of all working women in the administrative field at Princesses Nora University was 2897 female employees and sample consisted of 200 working women were selected according to stratified random sampling method. Results showed that most working women who were exposed economic exploitation were married and they all hold bachelor degree. The results also showed that the husband was the one who exploited strongly the woman and the most significant ways of exploitation were to make the woman the responsible for children's expenses and stinginess of family expenses although of his financial capability .Moreover, the weakness of woman personality was considered one of the reasons that led to exploitation.
\end{abstract}

Keywords Exploitation, Economic Exploitation, Types of Exploitation, The Exploited Saudi Women

\section{Subject and Significance of the Study}

Islamic writing has highlighted whatever is mentioned in the religious heritage concerning the woman's rights and respecting her personality since she is the man's partner in humanity after she had suffered a lot in Al-Jahila and in other nations as well. There is no doubt that Islam frees the woman and raises her rank and it was so clear that Islamic Sharea' has equaled the women with the men in the divine discourse in terms of faith, good work and punishment and rewarding in Judgment Day and there is also no arguments that verses in Quran and Sauna approved the woman's total eligibility in her economic actions in terms of having passport, the will, purchasing and other economic transactions even she was given the right to have her own money as the holy verse indicates: "Unto men a fortune from that which they have earned, and unto women a fortune from that which they have earned" An-Nisa' (32). ${ }^{(1)}$

The general image of Arab woman and the Saudi woman in particular reveals that she still lives in "brittle" circumstances in some rights including the economic ones and this is shown clearly of her current suffer because of the others' assault on her rights which are protected by Islamic Sharea and the modern systems. In the same context, the statistics of Arab Institution of Human Rights for the year 1999-2000 showed that the Arab working woman's wage rate in different countries compared with men's wages ranged from $30 \%$ to $70 \%$ of their wages. In other words, the women are considered cheap work force because of the limited available possibilities of work for her.

Recently, in the Saudi society, the number of the issues presented to the court concerning the Saudi women who were exploited economically by the men has increased .

And according to the judge Abdallah Bahlal in the Sharea' courts , $30 \%$ of Saudi women are exposed to the economic exploitation by the men and these practices vary ; misuse of some the legislative documents, or through using the woman's name to issue some commercial businesses without her knowledge ,or through forcing her to marry in a very young age to take her dowry, or forcing her to sell her properties, or keeping her without marriage to have her salary or to oblige her to borrow from the banks $\left(^{2}\right)$.

This study stemmed its practical importance from the fact that the women issues do not separate from its society and the statues of the social development in general and there is a conditional association between having a developed society in one hand and expecting a progress in the field of woman rights and being equal with the man in rights and duties which were issued by Islamic Sharea`on the other hand.

It is worth mentioning that the interest in studying economic exploitation of working woman in Arab societies has not been discussed into details and it has not been addressed by the researchers and scholars because of its 
relation to the inherited social traditions and habits which assured the woman's respect to family especially the husband and the brother and not to argue with them regarding her money even it was her right ${ }^{(3)}$. Although of the scarcity of the studies in Arab societies but there are related studies to the study's subject as the study of Huang(2012) which aimed to examine the effect of economic exploitation in the mothers' mental health. Its results concluded that after controlling demographic factors, age, race, education level, the mothers who were exploited economically, were depressed with a rate1.9 more than who were not exploited . while the rate of those who were exploited physically was 1.8 more than who were not and this reveals the horrible psychological effect as a result of the economic exploitation. And the study also clarified that the exploited woman economically showed low participation in the family activities with a rate 5.1 more than the women who were not exploited economically; whereas, in the field of slapping as a punishment, there were superior withal rate 1.5 which clarifies the horrible effect of economic exploitation not only on the woman and the family but also on the whole society.

One of the most important studies that discussed violence against the woman in USA was entitled by: "Violence Against Women, Development of the Scale of Economic Abuse". This study was prepared and conducted by Adrienne E. Adams, Cris M. Sullivan, Deborah Bybee and Megan R. Greeson (2008) and it addressed the shortage in the studies of economic exploitation towards the woman compared with other issues that attracted the researchers' interest and analysis as physical, psychological and sexual exploitation towards the woman. This study did notes usual documented the forms of economic exploitation and its effect on the woman but it summarized some previous studies which addressed the same topic. The study divided the strategies or methods used my men to exploit the woman economically into two parts: the first one was named strategies of preventing the woman from using the her own resources including different practices: determining the allotted money that covers the woman's sufficient expenses as food ,or giving her a little amount of money, or preventing her from using her of their common car forcing her to use the public transport. . (4)

While the other part is represented by the strategies and methods used by the man to utilize his partner's financial resources as stealing from her handbag, orate theft or use it without her permission ,or borrowing money using her names ,or stop paying the rent of the house or its bills. Additionally, he tries to destroy some of her valuable properties as the car. The study assured that all the respondents were exploited psychologically whereas $98 \%$ of them were exploited physically . Amazingly, $99 \%$ of them were exploited economically and so the study proved practically ion that woman's economic exploitation is a major component in the system of exploitation which is used to control the woman.

The study of Rana Ejaz, Ali Khan, Sara Noreen , Sara Ahmad(2012) aimed to analyze the economic exploitation of women in formal sector in Pakistan. It is based on 504 observations collected from 57 private as a sample of the study. Results showed that age of the teacher, her education and experience, household per-capita income, school age negatively influence the probability of economic exploitation of teachers. The study showed that if the woman's years of education increase, she will be more aware of her legal and civil rights. .(5)

A study (2011) entitled by " the woman and poverty in Yemen" focused on the relation between early marriage and woman's poverty in Yemeni society. Results revealed that early marriage is considered one of the basic reasons of woman's poverty that prevented her from education, working, or getting sufficient training that enable her to get a job and this was considered unfair for the woman and an assault on her freedom of choice as the woman becomes as a thing that can be sold and bought under " marriage" which is mainly equivalent . .(6)

A workshop organized about the Arab woman's economic rights in Mananah-Bahrainin 2013 proposed many recommendations concerning the economic aspect in item 3 of the Arab document of woman's rights as the necessity to take some procedures to revise the legislations and to illuminate any sign of discrimination and to make sure that the national legislations are compatible with international commitments; in addition to form legislations for establishing a financial entity allocated to motherhood to help the working women in the private sector through participation of the woman ,the state and the private sector . The Arab document also assured the necessity to take any action to protect the woman from the social and economic exploitation and to improve her living circumstances.

The objectives of the study

1. To identify the social and economic characteristics that distinguish the woman who is exposed to the financial exploitation.

2. To identify the extent to which the issue of Saudi woman's financial exploitation is spread .

3. To identify types of Saudi woman's financial exploitation.

4. To identify reasons of Saudi woman's financial exploitation.

5. To conclude some indicators that protects the woman from exploitation.

\section{Terms of the Study}

Exploitation : the verb " to exploit" indicates the following meanings : utilizing the land means getting benefit of it, to exploit a person means to get benefit of him or her without any right, to exploit a person's ignorance means to get benefit of him through devious means and to utilize his personal relations to achieve his goals, to exploit others' feelings means to utilize others' emotions and the industrial countries exploit the poor countries means to get benefit of it(7).In the dictionary of "Al- Monjed in the modern Arabic 
language", the word exploitation means : " a person's use of a mean to achieve something, or to get benefit of others' kindness or ignorance to get unfair profits". (8)

Economic exploitation : It includes every behavior leads to the control of other's ability in using the economic resources or keeping them in away threatens his economic security and his ability of self- -sufficiency (9). In addition to force him to rely on the exploiter financially (10). or it is : " the illegal or unauthorized use of other's properties or money, or any of his valuable things through fraud, or through having an official document that allow him to deprive others' prosperities' and money(11) . And Kottle (2009) divided the economic exploitation into two main different forms ; the first one occurs when the individual or a group of people have to accept tough or unfair work conditions and under bad and unsecure circumstances and it is called consensual exploitation which is mainly considered "exploitation under labor Law" (12) . The other form of economic exploitation is called Nonconsensual exploitation which includes elements as obligation or fraud and types of practices as human trafficking, children employment and physical exploitation.

The exploited Saudi woman: the Saudi woman which is exposed to a behavior or action from people around her as family and this exploitation harms the woman financially or morally that causes a waste of legal and legitimate rights.

\section{Reasons of Woman's Economic Exploitation and its Effects}

There are many theoretical studies and different opinions about reasons of woman's exploitation. It is a circle where there are many interlocking factors that cannot be separated during any discussion. Many experts believe that the unequal relations of authority between man and woman in the society are considered the basic factor in exploiting the woman in addition to other personal factors that control the size and the degree of exploitation. Therefore, levels and degrees of woman's exploitation vary from one environment to another and according to her age as well. The woman's social status is considered an important factor and a part from the social heritage that helps in exploiting her. Additionally, this social heritage is an important factor in reducing the woman's capabilities and so exploiting and punishing the woman by those who surround her becomes a group work against the woman. (13)

In the Arab societies in general and the Saudi one in particular, the nurture process of the males differs from the females' because the traditional culture's view believes that the two sexes should be prepared for different roles and so the differences in nurture tend to be in favor of the males. The little girl from the early beginning starts receiving messages as : the boy is better than the females, it is unexpected to have a male who participates in work at home, the woman's value depends on her beauty and her ability to have children . it is clear that the woman ,according to the
Arab traditional culture, has to have a man whom she should rely on and she is useless without the man. On the other hand, the little boy received different messages that qualify him to be the leader and to have the control. Showing passion of feelings is a sign of weakness that suits only the woman . This type of nu nurture leads to the discrimination between males and females which enhances father's authority in the family . (14)

This traditional view helps in creating " common culture" about the image of the woman based on the cultural heritage that sees the woman as a weak creature who needs help and protection. Unfortunately, the woman herself starts to believe in this image and she believes also that she should obey whatever her husband days or does. And she should tolerate because this is her destiny. This situation is a logical result to a continuous and organized process started when the woman was a child that should obey what others ask her to do till she becomes young..(15)

Consequently, the woman's economic ,social and cultural rights as right of work and have equal wage as the man's, getting benefit of the technological and scientific progress could not be achieved unless the woman obtain an suitable level of education. According to physical exploitation in the family, we do not have any study confirmed that the education level has any impact on this type of exploitation ; regardless the woman's level of education, the woman is exploited and in a study entitled by : "woman's economic exploitation : what is hidden in the domestic violence", a survey was carried on 25 organization and agency working in the field of domestic violence and which provided services to more than 52000 a woman survive from the domestic violence . Results showed $70 \%$ of the respondents got education level which is higher than secondary level, or the university level and $23 \%$ of the respondents finished their moderate education. Similarly, in another study by Adrienne E. Adams, Cris M. Sullivan, Deborah Bybee and Megan R. Greeson(2008), results showed that $88 \%$ of the respondents (103) who were exploited economically by their partners finished their secondary or university education which indicated that level of education is not a critical factor in this type of exploitation(16). In the same context, we do not have any study links the woman's age and economic exploitation . Based on the previous studies, we concluded that the age of exploited woman does not indicate any significance regarding the identification of the economic exploitation process.

The family's economic situation may have some influence according to some studies. The World Bank statistics indicate that $50 \%$ of the women exposed to human trafficking are from poor families and in the same study, $70 \%$ of the employees of the associations and agencies assured that half of their clients, at least, were very poor . Moreover, the legal factors or the situations have direct influence as the mechanism of applying the systems participate in the woman's exploitation cases the expert's weak scientific rehabilitation in the judicial institution, carelessness of the executive parties in judicial provinces' 
implementation concerning woman's rights represented by the department of Civil Rights and Civil Status Department in addition to the man's misuse of his right in divorce and other reasons help in slowing down the woman's obtaining her legal rights. ${ }^{(17)}$

\section{Effects of Economic Exploitation on the Woman}

Economic exploitation as one of the forms of violence affects the woman and her life in many different ways ; economically, psychologically and socially. Undoubtedly, the direct and the indirect effects that resulted from woman's exploitation cannot be ignored . many researchers think that there are psychological effects as feeling insecure, depressed, inability to raise children, socially isolated and low self-esteem. A study by Jasinski \& Williams( 1998) examined researches' results about woman's exploitation and different types of abuse she faced during twenty years showed that exploitation had many effects not only on the woman but also on the children; psychologically, socially, economically and healthy. .(18)

The direct economic effect is represented by the woman's loss of her financial resources and savings which threatened her economic ability in the short and long term so she becomes unable to save basic living components ; therefore she becomes totally economically dependable on the exploiter and this reason was considered according to many studies as the great obstacle that prohibits the exploited woman from leaving the exploiter and continues her life with him because if she refuses to stay with him, she will face dark and difficult future without having any economic resources especially if she has no experience and work skills. .(19)

The indirect effects of the financial exploitation can be seen in the woman's health as a result of her economic resources' deterioration and her bearing to great pressure in managing her living affairs. And this was confirmed by the study of Ratner (1998) which was conducted in the Canadian society; psychologically results showed the financial exploitation makes the woman suffers from headache, sensitivity, and backache which in turns affects the quality and quantity of her food, moreover, it affects negatively her general health and she may suffer from anxiety, depression, desire to commit suicide, and lack of self-confidence. This previous study agreed with the study of Ewing (1989) which aimed to examine the most important reasons of women's depression by selecting a sample consisted of 400 females. Results showed that $25 \%$ of them suffered from depression because of being exploited continuously.(20) . In all cases of woman's exploitation, her feeling of self-respect is reduced and her self-confidence is lost and so the woman will no longer has self-confidence or has the ability to manage her daily affairs. In some cases, the woman keeps herself away from social activities, people, family and friends which may affect her mental health. .(21)
The woman who is exploited financially suffers from many social problems as divorce or inability to raise the children when she decided to face $\mathrm{hm}$. Many studies attributed the woman silence and not to announce any exploitation, or disclosed it to unavailability of the having a secure place or any other source of income in case she quit her job especially if the exploiter was the husband. The woman who is exploited economically "mainly lives in isolation from her society and her social relations are limited plus her family circumstances are confused (Dobash\&Dobash,1979: 437:244 ).The economic exploitation is an apparent violation to the international agreements and standards as the international announcement of human rights pointed in article (23) that everyone has the right to work, and every individual without any discrimination has the right in equal wage at work. ${ }^{(23)}$

\section{Questions of the study}

The study treats the problem of Economic exploitation of the Saudi working woman through answering the following questions:

1. What is the extent of the spread of Economic exploitation of the Saudi working woman issue?

2. What are the economic and social characteristics that distinguish the woman who is exposed to the economic exploitation?

3. What are the social categories that exploit the working woman economically?

4. What is the type of the economic exploitation that faces the Saudi woman?

5. What are the reasons of the Saudi woman's economic exploitation?

\section{Methodology}

The study's type \&Approach: the study relies on the social survey approach because it is one of the major approaches used in the field of descriptive approaches and it is the first study that addressed the working woman's economic exploitation.

Population \& sample of the study: the field study is limited to the economic exploitation of the Saudi working woman and the population of the study which represents the working women in the administrative field at Princess Nora bint Abdulrahman University in Riyadh city consisted of 2897 administrative. The sample of the study which was selected using stratified random sampling consisted of 200. The valid number of questionnaires for statistical analysis was 191 questionnaire with a response $(90 \%)$ which is considered a good proportion to achieve the study's goals.

The study's instrument : to achieve the goals of the study and answer its questions, the researcher developed her own instrument(questionnaire) which consisted of two parts : the first one includes of the basic information concerning 
economic exploitation because of job and salary in addition to general questions about the demographic, social and economic characteristics include age, period of marriage , marital status, scientific qualification, experience, nature of work and family income while the second part includes questions about the economic exploitation, women reaction towards exploitation, reasons of exploitation and its rate plus indications of the reactions of the exploited one.

Instrument validity: The instrument was displayed in the preparation stage to five arbitrators who are expert in the fields of : social service, sociology, economy, law and Sharea ( Islamic religion) taking into account their notes. Interviews were carried with the population of the study.

Instrument reliability: The researcher applied Test - Retest method on a sample consisted of 10 females who has the same characteristics of the population of the study. The instrument's reliability coefficient which was calculated using Cronbach's alpha was 0.89and it is considered a high degree of the questionnaire's reliability that help in achieving the goals of the study.

\section{Results: Analysis \&Discussion}

$1^{\text {st }}$ question: What are the economic and social characteristics that distinguish the woman who is exposed to the economic exploitation?

Table( 1) illustrates that the age of more than half of the respondents ( $54.2 \%$ ) ranges from 25 to less than 32 , followed respectively by $29.5 \%$ whose age ranges from 32 to less than $39,8.9 \%$ whose age ranges from 18 to less than 25 , $6.3 \%$ whose age ranges from 39 and less than 46 and $1.1 \%$ whose age ranges from 46 and more .

Table 1. Economic and social characteristics that distinguish the woman who is exposed to the economic exploitation

\begin{tabular}{|c|c|c|c|c|c|}
\hline Age category & Freq. & Prop. & Marital status & Freq. & Propr. \\
\hline 18-less than 25 & 17 & 8.9 & Never married & 56 & 29.3 \\
\hline 25-less than 32 & 103 & 53.9 & Married & 118 & 61.8 \\
\hline 32- less than 39 & 56 & 29.3 & Divorced & 16 & 8.4 \\
\hline 39-less than 46 & 12 & 6.3 & Total & 190 & 99.5 \\
\hline 46 and more & 2 & 1.0 & Missing value ( no answer) & 1 & 0.5 \\
\hline Total & 190 & 99.5 & Sample's size & 191 & 100 \\
\hline Missing value (no answer) & 1 & 0.5 & Scientific qualification & Freq. & Prop. \\
\hline Sample's size & 191 & 100 & Secondary & 17 & 8.9 \\
\hline Period of marriage & Freq. & Prop. & Diploma & 15 & 7.9 \\
\hline Less than I year & 14 & 10.4 & Bachelor & 146 & 76.4 \\
\hline 1-less than 4 & 27 & 20.1 & Master & 9 & 4.7 \\
\hline 4-less than 8 & 29 & 21.6 & Others & 1 & 0.5 \\
\hline 8-less than 12 & 28 & 20.9 & Total & 188 & 98.4 \\
\hline 12-less than 16 & 16 & 11.9 & Missing value & 3 & 1.6 \\
\hline 16 and more & 14 & 10.4 & Sample's size & 191 & 100 \\
\hline Total & 128 & 95.5 & Work nature & Freq. & Prop. \\
\hline Missing values (no answer) & 6 & 4.5 & Administrative employee & 87 & 45.5 \\
\hline Size of the sample & $134^{*}$ & 100 & Secretary & 28 & 14.7 \\
\hline Income & Freq. & Prop. & Incoming \& outgoing officer & 17 & 8.9 \\
\hline No fixed income & 15 & 7.9 & Others & 16 & 8.4 \\
\hline Less than 2000 SR & 2 & 1.0 & Data entry & 11 & 5.8 \\
\hline 2000-4000SR & 10 & 5.2 & Public relations & 10 & 5.2 \\
\hline 4000-less than 6000SR & 16 & 8.4 & Translator & 8 & 4.2 \\
\hline 6000-less than 8000 SR & 32 & 16.8 & Office manager & 6 & 3.1 \\
\hline 8000 -less than 10000 SR & 32 & 16.8 & Employee & 1 & 0.5 \\
\hline 10000 and more & 84 & 44.0 & Total & 184 & 96.3 \\
\hline Total & 188 & 98.4 & Missing values & 7 & 3.7 \\
\hline Sample's size & 191 & 100 & Sample's size & 191 & 100 \\
\hline
\end{tabular}


The same table illustrates also that $62.1 \%$ of the respondents were married, $29.5 \%$ never be married and $8.4 \%$ were divorced . additionally, the working woman's period of marriage ranges from less than 1 year to more than 16 and the period of marriage of the most respondents ranges from less than a year to less than 12 with $65.7 \%$. The mean of the "period of marriage" was 7.8 years and the majority of the respondents were married .Regarding the information of the scientific qualification, results showed that $77.7 \%$ of the married working women got BA degree and $9 \%$ of them got secondary certificate while $8 \%$ got diploma and $4.8 \%$ got MA degree. But concerning the work nature ,results also showed the most of the respondents work as administrators with $47.3 \%$ followed respectively by secretaries with $15.2 \%$, who work in incoming \&outgoing office with $8.7 \%$, data entries with $6 \%$, public relations employees with $5.4 \%$, translators with $4.3 \%$, offices' managers with $3.3 \%$ and one employee with $0.5 \%$.

The same table showed that most of the respondents' families' income was $10000 \mathrm{SR}$ and more with $43.1 \%$ followed respectively by families whose income ranges between $8000 \mathrm{SR}$ and less than 10000SR with $17 \%$ and between 6000 and less than 8000 SR while the respondents whose income was between 4000SR and less than 6000SR were $8.5 \%$.About $8 \%$ of the respondents' families have no fixed income, $5.3 \%$ whose income ranges between 2000SR and 4000 SR and $1.1 \%$ whose income is less than 2000SR. the mean of the working women families was $8098.4 \mathrm{SR}$ and standard deviation $3372.5 \mathrm{SR}$.

In terms of the available data, the social characteristics of the sample of the study showed that the majority of them were married with moderate income and this category in particular suffers a lot at work especially when she works to help the family and to increase her income because she did not get any assistance from family or husband. She has great responsibilities; mother and wife in the family and a working woman outside where there was no place to take care of babies. Additionally, big number of these respondents faces difficulty in traffic and they lack the ability to drive in the Saudi society .More over most of the respondents were young ( this category which ranges between 25 and less than 32 is usually the target of the development plans ) and so this level of age suits the educational levels (Bachelor), years of experience which was less than 10 years for the majority which is an indication for a sufficient period of time at work to find out if there was an exploitation or not.

\section{Results of the second question: What is the extent of the spread of Saudi women economic exploitation's issue?}

It is clear from table 2 that $29 \%$ of the women were exploited by family and society because of their jobs and salaries while $71 \%$ were not exploited.

Because the woman's economic exploitation is one of the hidden issues which mainly occurred in a very closed family so these issues are not disclosed as a result of social, psychological and educational factors; in addition to the private cultural circumstances of the society as the Saudi's society. Result which showed that $26.7 \%$ of the respondents were exploited compared to $65.4 \%$ who were not exploited is considered an indication of the influence of these factors especially the question was straight forward in the beginning of the questionnaire which is not compatible with the respondents' answers for the following questions :

Table 2. Extent of working woman's exposure to economic exploitation

\begin{tabular}{|c|c|c|c|}
\hline Being exploited financially & Freq. & $\begin{array}{c}\text { Prop / } \\
\text { sample }\end{array}$ & $\begin{array}{c}\text { Prop/ } \\
\text { respondents }\end{array}$ \\
\hline Yes & $\mathbf{5 1}$ & $\mathbf{2 6 . 7}$ & $\mathbf{2 9 . 0}$ \\
\hline No & $\mathbf{1 2 5}$ & $\mathbf{6 5 . 4}$ & $\mathbf{7 1 . 0}$ \\
\hline Total & $\mathbf{1 7 6}$ & $\mathbf{9 2 . 1}$ & $\mathbf{1 0 0}$ \\
\hline Missing values( no answers) & $\mathbf{1 5}$ & $\mathbf{7 . 9}$ & $\ldots . . .$. \\
\hline Sample's size & $\mathbf{1 9 1}$ & $\mathbf{1 0 0}$ & $\ldots . .$. \\
\hline
\end{tabular}


Table 3. People who exploits the working woman

\begin{tabular}{|c|c|c|c|c|c|c|c|c|c|}
\hline Members & & Exploit strongly & Exploit & No exploit & Never exploit & No opinion & Total & Mean & Std \\
\hline \multirow{2}{*}{ Husband } & Freq & 35 & 72 & 33 & 21 & 18 & 179 & \multirow{2}{*}{3.5} & \multirow{2}{*}{1.2} \\
\hline & Prop & $\% 19.6$ & $\% 40.2$ & $\% 18.4$ & $\% 11.7$ & $\% 10.1$ & $\% 100$ & & \\
\hline \multirow{2}{*}{ Father } & Freq & 5 & 21 & 67 & 73 & 8 & 174 & \multirow{2}{*}{2.7} & \multirow{2}{*}{0.9} \\
\hline & Prop & $\% 2.9$ & $\% 12.1$ & $\% 38.5$ & $\% 42.0$ & $\% 4.6$ & $\% 100$ & & \\
\hline \multirow{2}{*}{ Brother(s) } & Freq & 7 & 39 & 62 & 54 & 11 & 173 & \multirow{2}{*}{2.9} & \multirow{2}{*}{1.0} \\
\hline & Prop & $\% 4.0$ & $\% 22.5$ & $\% 35.8$ & $\% 31.2$ & $\% 6.4$ & $\% 100$ & & \\
\hline \multirow{2}{*}{ Uncle } & Freq & 2 & 7 & 52 & 82 & 25 & 168 & \multirow{2}{*}{2.3} & \multirow{2}{*}{0.8} \\
\hline & Prop & $\% 1.2$ & $\% 4.2$ & $\% 31.0$ & \%48.8 & $\% 14.9$ & $\% 100$ & & \\
\hline \multirow{2}{*}{ Son } & Freq & 11 & 50 & 34 & 45 & 24 & 164 & \multirow{2}{*}{2.9} & \multirow{2}{*}{1.2} \\
\hline & Prop & $\% 6.7$ & $\% 30.5$ & $\% 20.7$ & $\% 27.4$ & $\% 14.6$ & $\% 100$ & & \\
\hline \multirow{2}{*}{ Uncle } & Freq & $\mathbf{0}$ & 8 & 51 & 84 & 25 & 168 & \multirow{2}{*}{2.3} & \multirow{2}{*}{0.8} \\
\hline & Prop & $\% 0.0$ & $\% 4.8$ & $\% 30.4$ & $\% 50.0$ & $\% 14.9$ & $\% 100$ & & \\
\hline \multirow{2}{*}{ Grandfather } & Freq & 0 & 4 & 47 & 88 & 29 & 168 & \multirow{2}{*}{2.2} & \multirow{2}{*}{0.7} \\
\hline & Prop & $\% 0.0$ & $\% 2.4$ & $\% 28.0$ & $\% 52.4$ & $\% 17.3$ & $\% 100$ & & \\
\hline \multirow{2}{*}{ Stepfather } & Freq & 6 & 11 & 39 & 60 & 42 & 158 & \multirow{2}{*}{2.2} & \multirow{2}{*}{1.0} \\
\hline & Prop & $\% 3.8$ & $\% 7.0$ & $\% 24.7$ & $\% \mathbf{3 8 . 0}$ & $\% 26.6$ & $\% 100$ & & \\
\hline \multirow{2}{*}{ Mother } & Freq & 0 & 21 & 56 & 81 & 8 & 166 & \multirow{2}{*}{2.5} & \multirow{2}{*}{0.8} \\
\hline & Prop & $\% 0.0$ & $\% 12.7$ & $\% 33.7$ & $\% 48.8$ & $\% 4.8$ & $\% 100$ & & \\
\hline
\end{tabular}

\section{Results of the third question what are the social categories that exploit the working woman economically?}

Results in table 3 showed that husbands came in the first rank in exploiting the working women with $59.8 \%$ as most of the respondents were married, followed respectively by sons and brothers with $37.2 \%$ and $26.5 \%$ with a mean 2.9 for the whole. Fathers with $15 \%$ and mean 2.7 followed respectively by uncles with $5.4 \%$, stepfathers with $10.8 \%$ and grandparents with $2.4 \%$.

Table 4. Types of working woman's exploitation

\begin{tabular}{|c|c|c|c|c|c|c|c|c|c|}
\hline Type of exploitation & & $\begin{array}{l}\text { Always } \\
\text { happen }\end{array}$ & Happens & $\begin{array}{l}\text { Never } \\
\text { happen }\end{array}$ & $\begin{array}{c}\text { Definitely not } \\
\text { happen }\end{array}$ & Neutral & Total & Mean & Std \\
\hline \multirow{2}{*}{$\begin{array}{l}\text { Having the whole salary or part of it with } \\
\text { the woman's satisfaction }\end{array}$} & Freq & 23 & 97 & 26 & 29 & 7 & 182 & \multirow{2}{*}{3.5} & \multirow{2}{*}{$\mathbf{1 . 0}$} \\
\hline & Prop & $\% 12.6$ & $\% 53.3$ & $\% 14.3$ & $\% 15.9$ & $\% 3.8$ & $\% 100$ & & \\
\hline \multirow{2}{*}{ To skimp alimony despite of his ability } & Freq & 54 & 75 & 24 & 17 & 9 & 179 & \multirow{2}{*}{3.8} & \multirow{2}{*}{1.1} \\
\hline & Prop & $\% 30.2$ & $\% 41.9$ & $\% 13.4$ & $\% 9.5$ & $\% 5.0$ & $\% 100$ & & \\
\hline \multirow{2}{*}{$\begin{array}{l}\text { Exploiting the woman's name in buying } \\
\text { and selling shares without her knowledge }\end{array}$} & Freq & 22 & 76 & 41 & 27 & 12 & 178 & \multirow{2}{*}{3.4} & \multirow{2}{*}{1.1} \\
\hline & Prop & $\% 12.4$ & $\% 42.7$ & $\% 23.0$ & $\% 15.2$ & $\% 6.7$ & $\% 100$ & & \\
\hline \multirow{2}{*}{ Forces her to borrow from banks } & Freq & 35 & 88 & 24 & 25 & 8 & 180 & \multirow{2}{*}{3.7} & \multirow{2}{*}{1.1} \\
\hline & Prop & $\% 19.4$ & $\% 48.9$ & $\% 13.3$ & $\% 13.9$ & $\% 4.4$ & $\% 100$ & & \\
\hline \multirow{2}{*}{$\begin{array}{l}\text { Exploiting the woman's money to marry } \\
\text { another one. }\end{array}$} & Freq & 16 & 82 & 30 & 32 & 17 & 177 & \multirow{2}{*}{3.3} & \multirow{2}{*}{1.2} \\
\hline & Prop & $\% 9.0$ & $\% 46.3$ & $\% 16.9$ & $\% 18.1$ & $\% 9.6$ & $\% 100$ & & \\
\hline \multirow{2}{*}{$\begin{array}{l}\text { Leaving the expenses of the children to } \\
\text { the working married woman. }\end{array}$} & Freq & 68 & 77 & 15 & 18 & 6 & 184 & \multirow{2}{*}{4.0} & \multirow{2}{*}{1.1} \\
\hline & Prop & $\% 37.0$ & $\% 41.8$ & $\% 8.2$ & $\% 9.8$ & $\% 3.3$ & $\% 100$ & & \\
\hline
\end{tabular}


Table 5. Causes of the economic exploitation and its rate

\begin{tabular}{|c|c|c|c|c|c|c|c|c|c|c|}
\hline Reasons & & $\begin{array}{c}\text { Happen } \\
\text { very often }\end{array}$ & $\begin{array}{c}\text { Happen } \\
\text { a lot }\end{array}$ & $\begin{array}{l}\text { Happened to } \\
\text { some extent }\end{array}$ & $\begin{array}{c}\text { Not } \\
\text { happen }\end{array}$ & $\begin{array}{c}\text { Definitely } \\
\text { not happen }\end{array}$ & $\begin{array}{c}\text { Not } \\
\text { clarified }\end{array}$ & Total & Mean & Std \\
\hline \multirow{2}{*}{$\begin{array}{l}\text { Personal reasons } \\
\text { concerning the exploiter }\end{array}$} & Freq. & 41 & 57 & 50 & 10 & 3 & 9 & 170 & \multirow{2}{*}{3.6} & \multirow{2}{*}{1.3} \\
\hline & Prop. & $\% 24.1$ & $\% 33.5$ & $\% 29.4$ & $\% 5.9$ & $\% 1.8$ & $\% 5.3$ & $\% 100$ & & \\
\hline \multirow{2}{*}{ Woman's weak character } & Freq. & 61 & 57 & 47 & 9 & 1 & 1 & 176 & \multirow{2}{*}{3.9} & \multirow{2}{*}{1.0} \\
\hline & Prop. & $\% 34.7$ & $\% 32.4$ & $\% 26.7$ & $\% 5.1$ & $\% 0.6$ & $\% 0.6$ & $\% 100$ & & \\
\hline \multirow{2}{*}{ Family low income } & Freq. & 38 & 64 & 56 & 13 & 4 & $\mathbf{0}$ & 175 & \multirow{2}{*}{3.7} & \multirow{2}{*}{1.0} \\
\hline & Prop. & $\% 21.7$ & $\% 36.6$ & $\% 32.0$ & $\% 7.4$ & $\% 2.3$ & $\% 0.0$ & $\% 100$ & & \\
\hline \multirow{2}{*}{$\begin{array}{l}\text { Social reasons ( inferiority } \\
\text { image of woman's work) }\end{array}$} & Freq. & 17 & 40 & 53 & 40 & 13 & 6 & 169 & \multirow{2}{*}{2.9} & \multirow{2}{*}{1.2} \\
\hline & Prop. & $\% 10.1$ & $\% 23.7$ & $\% 31.4$ & $\% 23.7$ & $\% 7.7$ & $\% 3.6$ & $\% 100$ & & \\
\hline \multirow{2}{*}{$\begin{array}{l}\text { Cultural reasons (the } \\
\text { woman should stay at } \\
\text { home) }\end{array}$} & Freq. & 15 & 45 & 68 & 26 & 9 & 6 & 169 & \multirow{2}{*}{3.1} & \multirow{2}{*}{1.1} \\
\hline & Prop. & $\% 8.9$ & $\% 26.6$ & $\% 40.2$ & $\% 15.4$ & $\% 5.3$ & $\% 3.6$ & $\% 100$ & & \\
\hline \multirow{2}{*}{$\begin{array}{c}\text { The belief that the woman's } \\
\text { leaving home for work, she } \\
\text { should pay tax from her } \\
\text { salary) }\end{array}$} & Freq. & 33 & 59 & 53 & 25 & 5 & 2 & 177 & \multirow{2}{*}{3.5} & \multirow{2}{*}{1.1} \\
\hline & Prop. & $\% 18.6$ & $\% 33.3$ & $\% 29.9$ & $\% 14.1$ & $\% 2.8$ & $\% 1.1$ & $\% 100$ & & \\
\hline \multirow{2}{*}{$\begin{array}{l}\text { Legal reasons ) lack of } \\
\text { systems that protect the } \\
\text { woman legally ) }\end{array}$} & Freq. & 50 & 56 & 42 & 16 & 5 & 4 & 173 & \multirow{2}{*}{3.7} & \multirow{2}{*}{1.2} \\
\hline & Prop. & $\% 28.9$ & $\% 32.4$ & $\% 24.3$ & $\% 9.2$ & $\% 2.9$ & $\% 2.3$ & $\% 100$ & & \\
\hline \multirow{2}{*}{$\begin{array}{l}\text { Society's lack of awareness } \\
\text { of importance of woman } \\
\text { work }\end{array}$} & Freq. & 37 & 58 & 51 & 18 & 4 & 5 & 173 & \multirow{2}{*}{3.5} & \multirow{2}{*}{1.2} \\
\hline & Prop. & $\% 21.4$ & $\% 33.5$ & $\% 29.5$ & $\% 10.4$ & $\% 2.3$ & $\% 2.9$ & $\% 100$ & & \\
\hline \multirow{2}{*}{$\begin{array}{l}\text { Fear of woman's financial } \\
\text { independence }\end{array}$} & Freq. & 42 & 63 & 39 & 17 & 4 & 5 & 170 & \multirow{2}{*}{3.6} & \multirow{2}{*}{1.2} \\
\hline & Prop. & $\% 24.7$ & $\% 37.1$ & $\% 22.9$ & $\% 10.0$ & $\% 2.4$ & $\% 2.9$ & $\% 100$ & & \\
\hline \multirow{2}{*}{$\begin{array}{l}\text { The husband's desire to } \\
\text { control his wife financially }\end{array}$} & Freq. & 41 & 65 & 45 & 14 & 7 & 1 & 173 & 7 & \\
\hline & Prop. & $\% 23.7$ & $\% 37.6$ & $\% 26.0$ & $\% 8.1$ & $\% 4.0$ & $\% 0.6$ & $\% 100$ & & 10 \\
\hline $\begin{array}{c}\text { Executive parties' } \\
\text { weakness in implementing }\end{array}$ & Freq. & 57 & 49 & 38 & 12 & 5 & 10 & 171 & & \\
\hline $\begin{array}{c}\text { judicial provinces } \\
\text { concerning women rights }\end{array}$ & Prop. & $\% 33.3$ & $\% 28.7$ & $\% 22.2$ & $\% 7.0$ & $\% 2.9$ & $\% 5.8$ & $\% 100$ & 0.0 & 1.4 \\
\hline Woman's ignorance of her & Freq. & 53 & 53 & 50 & 15 & 2 & 2 & 175 & & \\
\hline rights & Prop. & $\% 30.3$ & $\% 30.3$ & $\% 28.6$ & $\% 8.6$ & $\% 1.1$ & $\% 1.1$ & $\% 100$ & & \\
\hline Absence of legislations that & Freq. & 51 & 53 & 43 & 19 & 3 & 5 & 174 & 7 & 12 \\
\hline protect women rights & Prop. & $\% 29.3$ & $\% 30.5$ & $\% 24.7$ & $\% 10.9$ & $\% 1.7$ & $\% 2.9$ & $\% 100$ & & \\
\hline & Freq. & 53 & 57 & 39 & 20 & 4 & 2 & 175 & & \\
\hline & Prop. & $\% 30.3$ & $\% 32.6$ & $\% 22.3$ & $\% 11.4$ & $\% 2.3$ & $\% 1.1$ & $\% 100$ & & \\
\hline The woman's agent's & Freq. & 44 & 55 & 52 & 10 & 6 & 5 & 172 & & \\
\hline legal role & Prop. & $\% 25.6$ & $\% 32.0$ & $\% 30.2$ & $\% 5.8$ & $\% 3.5$ & $\% 2.9$ & $\% 100$ & 5.0 & 1.2 \\
\hline
\end{tabular}


Results of the fourth question: What are the types of the economic exploitation which the Saudi woman is exposed to?

Results in table 4 showed that the Saudi working woman faced different types of the financial and economic exploitation. Leaving children's expenses to the working married woman came first as the first type of exploiting the working woman financially with $(78 \%)$. About (72.1\%)of the working women assured that their husbands did not pay well despite of their financial ability and $68.3 \%$ of the working women said that they were obliged to borrow from the banks . And 55.4\% of them showed that their money was exploited to marry other woman. Results also revealed that $55.1 \%$ of the women whose names were exploited in buying and selling shares without their knowledge or permission.

\section{Results of the fifth question: What are the causes of the economic exploitation of Saudi working woman?}

Results showed that woman's weak character came as the first cause of economic exploitation with $93.8 \%$ and mean 3.9 , followed respectively by the family's low income with $90.3 \%$ and a mean 3.7, the woman's ignorance of her right with $89.1 \%$ with a mean 3.8 , the woman's agent 's misuse of his legitimate and legal role with $87.8 \%$ and a mean 3.6 , the husband's desire to control the woman financially with $87.3 \%$ and a mean 3.7 , perusal factors concerning the exploiter with 87.1 and a mean 3.6 , legal reasons with $85.5 \%$ and a mean 3.7 , the husband's unemployment with $85.1 \%$ and a mean 3.7 , fear of woman's financial independence with $84.7 \%$ and a mean 3.6 , absence of legislations that protect woman's rights with $84.5 \%$ and a mean 3.7 , society's lack of awareness of importance of woman's work with $84.4 \%$ and a mean 3.5 , weakness of the executive parties in implementing the judicial provisions regarding woman's rights with $84.2 \%$ and a mean 3.6 , the belief that the woman who goes out of her house should pay a tax with $81.9 \%$ and a mean 3.1 , cultural reasons with $75.7 \%$ and social reasons with $65.1 \%$ and a mean 2,9 . So it is not logic to say that there is one reason for exploiting the working woman as exploitation is a phenomenon with multi - reasons; economically, socially, psychology, culturally, educationally, and its concept varies from one culture to another. The researcher used indicators extracted from the previous studies and related literature examined the educational, psychological, social and economic. It was clear that weakness of character which is related to the woman's nurture, economic level, ignorance of rights, utilizing official papers in addition to lack of laws' protection were the most important reasons of woman's economic exploitation .

\section{Results Discussion}

In light of the data analysis, the study revealed the following results:

First: the social and economic characteristics of the exploited women have their significant role in this exploitation as it mainly occurs among the women whose age is more than 25 years and who hold BA degree and work as administrators, in addition to the women whose monthly income is more than $10000 \mathrm{SR}$.

Second: most of the woman's economic exploitation occurs after her marriage and leaving family house as $71 \%$ of the women were not exploited economically by the family.

Third: results of the analysis were compatible as table (3) showed that the husband is most social category that exploited the woman economically and this result also was compatible with the results in table (2) which showed that most working women were not exploited by the family and similarly with the results in table (1) which illustrated that working women with MA degree holders were the most exploited compared with the unemployed and single women.

Fourth: results illustrated that Saudi working women were exposed to different types of financial and economic exploitation by the husband. And the most significant types were respectively as follows: children expenses are the working and married woman's responsibility, the husband's stinginess of the alimony although of his financial capability, obliging the working women to borrow from the banks, taking the woman's whole salary or part of it without the woman's satisfaction or acceptance, the husband's exploitation of the woman's salary to marry another one and utilizing the woman's name in buying and selling the shares without their knowledge.

Fifth: the women's exploitation is attributed to the following reasons respectively: the weakness of the woman's character, the family's low economic level, the woman's ignorance of her rights, the woman's agent's misuse of his legal and illegitimate role and the husband's desire to control the woman financially.

\section{Most Important Precautionary Measures for Protecting the Woman from Economic Exploitation}

The judge of the Court of Personal Affairs in Saudia Arabia who cares much about problems facing the Saudi women showed his interest and support and his first note assured that the Saudi woman needs awareness of her legitimate financial rights and there are a set of precautionary measures that can protect the woman's financial rights:

- Document the woman's desire of continuing her work in the marriage contract .

- The woman should know that the husband has no right to prevent the woman from using her own money whether in purchasing, or renting and others based on Ibn Batal saying: " the Nation agrees that if the woman has control of herself, can purchase and sell and her husband has no right to show any objection," (Ibn Batal explanation in Sahih Bokhari,286/6).

- The woman should not work out without her husband's permission in case he did all his duties towards her and their children. But if he did not, the 
woman is not obliged to obey him when he prevents her from work( KashfAl-Gina',197/5).

- Legal consultation is necessary before signing any official document, or loan, or guarantee someone so that the woman can know her legal rights' responsibilities for her assignment.

- Educate the woman legally through sessions and extensive workshops that shed light on unclear legitimate and legal issues related to women.

\section{Recommendations}

In light of the results, the study recommends the following :

1. To establish an independent body cares about protecting the woman's economic rights and avoids negatives facing the speed of judging procedures to protect her rights.

2. To educate and aware the woman of her rights and duties through training in the civil society institutions and to organize specialized training courses in the legal and legitimate to aware her of her rights at work field.

3. To solve problems facing the Saudi working woman in the commercial field especially when they follow up their business in other ministries .

4. To aware the girls who are about to marry and the married of their rights and common duties between the couples as mutual cooperation and respect.

5. To establish an independent institution that cares of the woman's legitimate rights.

6. To aware the society of the woman's economic exploitation issue .

7. To activate the role of the social nurture institutions as (family school, mosques, cultural forums, media ) in the process of awareness and education in the field of human rights and stop exploiting her in any field and to look at her as a partner in life in the family and society.

8. To create work opportunities and new investments canals for women's work that help the private sector to have a purposeful role.

\section{REFERENCES}

[1] Holy Quran .An-Nisa. Aya (32).

[2] Morgan, G. A., Gliner, J. A. and Harmon, R. J. (2006) Understanding and evaluating research in applied clinical settings. Publisher: Lawrence Erlbaum Associates.

[3] Al-Bahlal, a lecture presented in Princess Nora Bint Abdrahman University , 1/2/1432 H.

[4] Adams, Adrienne; Sullivan, Bybee, Greeson (May 2008). "Development of the Scale of Economic Abuse". Violence Against Women.p33.
[5] "Ejaz, Rana Ali Khan, Noreen, Sara. and Ahmad, Sara: Economic Exploitation of Working Women in Formal Sector: A Case Study of Private School Teachers (Bahawalpur-Pakistan) World Applied Sciences Journal 20 (3): 481-486, 2012.

[6] Ali N Alfayiz, Maisoun, Marriage of little girls, center of perspective researches in the social researches and women studies,Riyadh,2011.

[7] Al-Salih,Misleh: Al-Shamel, Dictionary of social idioms . Dar Alim Al-Kinutotob for printing ,publishing \&distribution ,Riyadh ,1419 H.P524.

[8] Hamawi, Sobhi: Al-Monjed in Modern Arabic language , 2nd ed .Dar Mashraq,2001.P131.

[9] Adrienne E. Adams, Violence Against Woment, Development of the Scale of Economic Abuse, 2008 http:// www. Sagepublications.com.

[10] Saners, Cynthia. "Organizing for Economic Empowerment of Battered Women: Women's Savings Accounts". 2006. Journal of Community Practice, 14 (3), 47-68.

[11] Cramer, D. Basic Statistics for Social Research: Step-by-step Calculation and Computer Techniques Using Minitab ,1997, Rutledge, London.

[12] Johannes, Kottle, human trafficking, modern day slavery, and economic exploitation, Social protection and labor ,2009, discussion paper No o911.

[13] Manaa, Hythem: social structure \& woman progress, reports of Arab Development ,2005.

[14] Linda .L. Baker \& Alison .J. Cunningham. Learning to help-understanding women abuse and its effects 0 n children. the Centre for Children \&Families in the Justice System, Canada, 2005

[15] Hijazi, Mostafa: social backwardness: an entrance into human psychology ,9th ed, Arab cutlral center , Casablanca,2005.

[16] Adams, Adrienne; Sullivan, By bee, Gleeson (May 2008). Pp 11-14.

[17] Al-Bahlal,Op, 1/2/1432 H.

[18] Jasinski, J., \& Williams, L. Partner violence, New Delhi, Sage Publications, 1998.p218.

[19] Correia,A. L., \&Rubin, J. Housing and battered women: A case study of domestic violence program in Low. Retrieved, February 7, 2008. From http://new.vawnet.org/category/Mai n Doc.php?docid $=106$

[20] Crawford1, Emma, Liebling-Kalifani2, Helen and Hill, Vicki, Women's Understanding of the Effects of Domestic Abuse: The Impact on Their Identity, Sense of Self and Resilience. A Grounded Theory Approach. Journal of International Women's Studies Vol. 11 \#2 November 2009.

[21] Nunnally, J. C. psychometric theory (2nd ed.). New York: McGraw, 1978,

Hill.http://www.almaany.com/home.php?language=arabic\&l ang name)

[22] Dobash, R. E., \& R. P. Dobash"Wives: The appropriate Victims of marital violence" Victim1979 day 2: 42442.

[23] United Nation, document of international announcement of human rights, 1948. 